UDC 635.11:575.2:577.29:57.088.1

\title{
RAPD ANALYSIS OF COLLECTION ACCESSIONS OF THE GENUS Beta L. SPECIES
}

\author{
N.I. Vavilov Research Institute of Plant Industry, Russian Academy of Agricultural Sciences, 44, ul. Bolshaya Morskaya, St. Petersburg, \\ 190000 Russia \\ e-mail:yu.chesnokov@vir.nw.ru
}

Received April 11, 2012

Su m mary

\begin{abstract}
The primitive (transient) forms and wild varieties of beet are related to cultivated beet (sugar, table, fodder and mangold), have the useful properties, can be crossed with cultivated beet and used in breeding programs. However, there are some difficulties in estimating the status of beet samples and procedure for their storage in gene banks, which are caused by problems in beet taxonomy and systematics. In particular, a correct discrimination of Beta maritima vs $B$. vulgaris is hard to accomplish, and also the distinctions between $B$. maritima and $B$. adanensis or $B$. macrocarpa are difficult to identify. With the use of classical morphobiological analysis and molecular RAPD-markers, the authors for the first time determined the phylogenetic relationships between different specimens of wild, primitive and cultivated Beta $\mathrm{L}$. from world collection of the N.I. Vavilov All-Russian Scientific Research Institute of Plant Growing (VIR). On the basis of electrophoresis data, by means of UPGMA method the tested samples were clustered and phylogenetic trees created. The obtained data suggest the phylogenetic division of Beta $\mathrm{L}$. genus, which have been proposed by V.I. Burenin in 1983, and indicate an accuracy of this classification.
\end{abstract}

Keywords: species of Beta L. genus, RAPD analysis, phylogenetic interactions.

A wide variety of beets (Beta L.), both cultivated and wild representatives of different countries, were analyzed by N.I. Vavilov (1) along with scientific world literature available at that time, which data he used to identify the two world centers of origin of the genus Beta in Central Asia and Southwest Asia. According to various reports, there are focused from 13 to 15 wild species and 23-25 primitive forms transitional from wild to a crop $(2,3)$.

Primitive (transitional) beets and wild Beta species are close to cultivated forms (sugar, table, leaf, fodder beets), and, therefore, they are an important source of germplasm. Such species have valuable features and crossability with cultivated beets, they can be directly used in breeding programs $(2,4)$. Their useful properties are: heterothallism, cytoplasmic male sterility (CMS), resistance to low temperature and soil salinity, immunity to diseases and pesticides.

Among the 15 species in the genus Beta L. there are five wild dioecious (monospermic) species (B. pattelaris, B. procumbens, $B$. webbiana, $B$. lomatogona, B. nana), and 10 polyspermic species including cultivated beet. In the view of Vavilov's law of homologous series (5), heterothallism may occur among cultivated beets as well, which then was confirmed by Russian and American researchers. Today, heterothallic sugar beet varieties predominate in crops of major sugar beet producers in the Europe and America. Later, heterothallic forms were also identified in table and fodder beet cultivars $(2,3)$.

Some features, such as immunity to viruses and rhizomania (6), anatomy of root (7), resistance to nematodes (8) were transferred into sugar beet by conventional breeding. Wild sources of CMS were used to increase diversity of beets and thus improve its resistance to diseases associated with high cytoplasmic homogeneity (9). Wild beet species are also of interest because some of them have a very short life cycle: they produce flowers and seeds in 10-15 weeks (unlike biennial cultural beets), which allows conducting genetic, molecular-biological or breeding studies of many generations in a very short time.

High economic and scientific value of the germplasm is the reason for establishing collections of the genus Beta stored in different seed banks. However, curators of such collections report about some problems associated with storage, reproduction, and unclear status of samples $(3,10)$ - primarily, their taxonomy and systematics, such as a correct discrimination of $B$. maritima vs $B$. vulgaris, as well as $B$. maritima vs $B$. adanensis or $B$. macrocarpa. Clarifying these issues is essential for characterization and preservation of these samples in gene banks.

The development of RAPD analysis (random amplified polymorphic DNA) (11) had provided a new tool for scientific research that was applied on many plants (12). This method is used in a quite wide range of studies - genetic diversity within species, design of molecular markers for selection (13), genetic mapping of various species (14) including beet $(15,16)$, etc.

Genetic relations of wild and cultivated beets were investigated using different molecular markers. They were used in genetic mapping and breeding research, in studies of somaclonal variation observed in cells and tissues cultured in vitro. These approaches included assessing isozymes (17-19), RFLP (19-23), SSR (24), RAPD (15, 25), and some specific tests (26). M. Lorenz et al. (25) performed RAPD analysis of total, nuclear, mitochondrial, and chloroplast DNA in two near-isogenic lines of sugar beets (CMS and fertile one), which revealed clear differences in their RAPD-spectra of chloroplast or mitochondrial DNA. Thus was demonstrated capability of RAPD method for detecting different types of cytoplasm. In another study (15), sugar beets (one of altissima Doell.) was mapped using 50 RAPD- and 248 RFLP-markers, as well as three classic marker loci $(R r l, R, M)$. The obtained results suggested that RAPD-fragments can serve as good and reliable markers of genomic regions containing repetitive DNA sequences .

In this research, RAPD markers were used to reveal relationships between and within species of the genus Beta L. in order to establish phylogenetic relations of wild and cultivated beets preserved in the World collection of N.I. Vavilov Research and Development Institute of Plant Industry (VIR).

Technique. The tested samples included wild beets - B. perennis (designation in VIR catalogue: k-2045, origin: Azerbaijan), B. maritima (k-1368, England), B. macrocarpa (k-1788, Canary Islands), B. spontaneus (k-1365, Italy), B. orientalis (k-644, India), B. cicla (k-45, Germany), as well as cultivated and primitive samples of B. vulgaris - Bordo 237 (k-201, RF), Ramonskaya odnosemyannaya 47 (k-2953, RF), Ekkendorfskaya zheltaya (k-2028, RF), Kitayskaya belaya (k-610, Cyprus), Abkhazskaya zelenolistaya (k-947, Georgia), Adanskaya zheltaya (k-123, Turkey), Afyonkarahissarskaya (k-117, Iran), Chardzhuyskaya (k-1419, Uzbekistan), Zimnyaya ovalnaya (k-1296, RF), Poludlinnaya krasnaya (k-970, RF), Dlinnochereshkovaya belaya (k-159, Armenia), Turkestanskaya zelenolistaya (k-648, Georgia), Polosatochereshkovaya (k-169, Cyprus) from the World plant collec- 
tion of VIR.

DNA was isolated by standard methods as described previously (27). Purity and concentration of the derived DNA was assessed spectrophotometrically. DNA was considered pure if extinction ratios $\mathrm{OD}_{260 / 230}$ and $\mathrm{OD}_{260 / 280}$ were within $1.8-2.0$. Concentration of the DNA was additionally determined by electrophoretic analysis in 1.5\% agarose gel in TBE-buffer with standard markers 1kb DNA Ladder GeneRuler ("Fermentas", Lithuania).

PCR amplification and subsequent electrophoretic analysis were performed using the earlier proposed method (28). DNA of the investigated samples was analyzed by RAPD with ten-dimensional oligonucleotide primers from sets A (OPA 1 - OPA 20) and C (OPC 1 - OPC 20) manufactured by "Operon Technologies" (California, USA). PCR amplification was conducted in the reaction mixture (volume - $12.5 \mathrm{ul}$ ) that included a single incubation buffer, $\mathrm{MgCl}_{2}(1.5 \mathrm{uM})$, dNTP $(100 \mathrm{uM}$ of each), 0.25 units Taq DNA polymerase ("Qbio-gene", Germany), and $20 \mathrm{ng}$ genomic DNA. Thermocycler ("BioRad", USA) was programmed for initial denaturation at $94{ }^{\circ} \mathrm{C}$ for $3 \mathrm{~min}$ followed by 45 cycles (annealing- $36{ }^{\circ} \mathrm{C} 1 \mathrm{~min}$, extension $-72{ }^{\circ} \mathrm{C} 2$ min, denaturation $-94{ }^{\circ} \mathrm{C}$ $0,3 \mathrm{~min}$ ) and final elongation at $72{ }^{\circ} \mathrm{C}$ for $10 \mathrm{~min}$.

Amplification products were analyzed in 1.5-2.0 \% agarose gel in TBE- buffer. The gels were stained with ethidium bromide and photographed under UV light using gel documentation system ("BioRad", USA). Electrophoretic profiles were examined visually assessing the number of bands for each sample. The case of a marker band present or absent in each electrophoretic track was denoted as, respectively, 1 or 0 . Only distinct bands were considered, doubtful ones were ignored assuming them absent.

Genetic distances were established by pairwise comparison of samples using the method of M. Nei and W.H. Li (29) and the formula: GS $=2 n_{\mathrm{xy}} /\left(n_{\mathrm{x}}+n_{\mathrm{y}}\right)$, where GS - genetic similarity; $n_{\mathrm{x}}$ и $n_{\mathrm{y}}$ - number of electrophoretic bands in samples x and y, $n_{\mathrm{xy}}-$ number of bands common in both compared samples. Polymorphism within each sample or within an identified group was evaluated by the frequency of polymorphic bands in a ratio to total number of observed bands, or by Shannon-Weaver index (30). The value of $\chi^{2}$ was determined upon recorded numbers of polymorphic and homologous bands. Phylogenetic trees were constructed using UPGMA method of unweighted pair-group cluster analysis with arithmetic mean ( 31) and the program NTSYS-pc (32).

Results. Phylogenetic relationships between the studied samples were determined using RAPD analysis conducted twice for each sample. Since there observed were small test-retest differences due to statistical experimental error, the following calculations were conducted considering only the data of amplicons not varying between replicates. To avoid errors caused by heterogeneity of a particular sample (each one included the material of 12 plants), total DNA was extracted from each plant separately and then mixed in equal proportions.

In preliminary experiments, each tested sample was composed from a few randomly chosen plants whose DNA was investigated individually by RAPD-analysis. There were tested 40 primers, and according to these results the authors selected 19 polymorphic primers capable to identify polymorphism within a sample or between the studied samples.

A

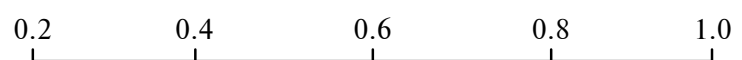

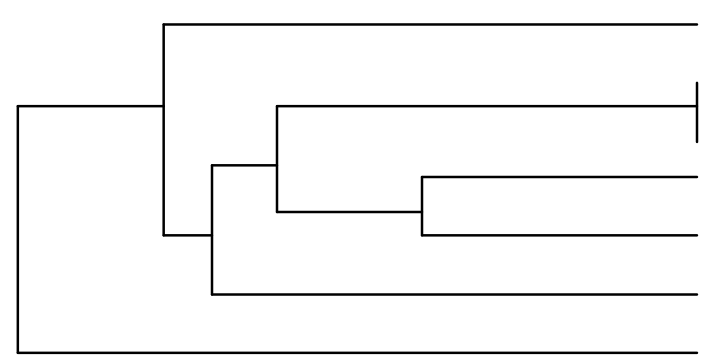

0.2

0.4

0.6

0.8

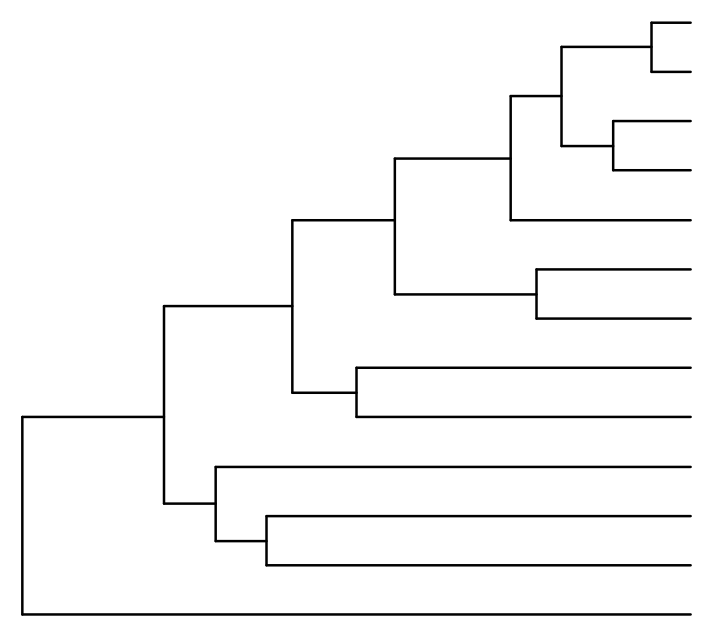

B. macrocarpa

B. spontaneus

B. orientalis

B. cicla

B. vulgaris (cv Bordo 237)

B. maritima

B. perennis

1.0

Bordo 237

Ekkendorfskaya zheltatya

Ramonskaya odnosemyannaya 47

Kitayskaya belaya

Abkhazskaya zelenolistaya

Afyonkarahissarskaya

Adanskaya zheltaya

Chardzhuyskaya

Zimnyaya ovalnaya

Dlinnochereshkovaya belaya

Turkestanskaya zelenolistaya

Poludlinnaya krasnaya

Polosatochereshkovaya

Dendrogram of phylogenetic relationships between wild beets (A) and cultivated Beta $\mathrm{L}$. species (B) constructed with UPGMA clustering method.

Subsequent RAPD-analysis was performed on bulk DNA of each sample and the 19 selected primers. Resulting 
electrophoretic RAPD profiles exhibited polymorphism between the studied samples. In total it was identified 63 polymorphic markers, and each of them was assessed with construction of dendrograms by UPGMA method in order to establish phylogenetic relationships between the studied samples.

Thus, it was shown clustering of wild-type beet forms (Figure, A) suggesting B. perennis as the most ancient species among the studied samples and the ancestor of $B$. macrocarpa and B. maritima, while B. maritima was a possible ancestor of $B$. spontaneus and $B$. orientalis. According to the dendrogram, B. spontaneus and B. orientalis can be assumed as members of one species rather than different taxa. Two other species - B. cicla and B. vulgaris (cv Bordo 237) belong to an independent cluster, which, along with the cluster spontaneus/orientalis, has a common origin with B. maritima.

Genetic polymorphism of the seven studied wild-type samples is illustrated by data presented in Table 1.

1. Degree of RAPD polymorphism of the seven wild-type samples of different Beta $\mathbf{L}$. species from the World collection of N.I. Vavilov Research Institute of Plant Industry (VIR).

\begin{tabular}{|c|c|c|c|c|c|c|c|}
\hline Sample & $\begin{array}{l}\text { B. pe- } \\
\text { rennis }\end{array}$ & $\begin{array}{l}\text { B. mari- } \\
\text { tima }\end{array}$ & $\begin{array}{l}\text { B. macro- } \\
\text { carpa }\end{array}$ & $\begin{array}{c}\text { B. sponta- } \\
\text { neus }\end{array}$ & $\begin{array}{l}\text { B. orien- } \\
\text { talis }\end{array}$ & $\begin{array}{l}\text { B. cic- } \\
\text { la }\end{array}$ & $\begin{array}{l}\text { B. vulga- } \\
\text { ris } \\
\text { (cultivar } \\
\text { Bordo } \\
237 \text { ) }\end{array}$ \\
\hline & 0.141 & $\begin{array}{c}\mathrm{reque} n \\
0.537\end{array}$ & $\begin{array}{c}\text { of p o l y } \\
0.543\end{array}$ & $\begin{array}{c}\mathrm{rph} \mathrm{i} \mathrm{c} \mathrm{ba} \\
0.500\end{array}$ & 0.500 & 0.187 & 0.193 \\
\hline & 0.14 & $0.41^{\mathrm{Sh}}$ & $\begin{array}{c}o \mathrm{n}-\mathrm{W} \text { e a } \\
0.41 \\
\chi^{2}\end{array}$ & $\begin{array}{c}\mathrm{r} \text { I n d e x } \\
0.40\end{array}$ & 0.39 & 0.16 & 0.17 \\
\hline B.perennis & & $<0.001$ & $<0.01$ & $\mathrm{nr}$ & $\mathrm{nr}$ & $<0.05$ & $<0.05$ \\
\hline B. maritima & & & $\mathrm{nr}$ & $<0.001$ & $<0.05$ & $<0.01$ & $<0.001$ \\
\hline B. macrocarpa & & & & $<0.05$ & $\mathrm{nr}$ & $<0.05$ & $\mathrm{nr}$ \\
\hline B. spontaneus & & & & & $<0.001$ & $<0.05$ & $\mathrm{nr}$ \\
\hline B. orientalis & & & & & & $\mathrm{nr}$ & $<0.05$ \\
\hline B. cicla & & & & & & & $<0.001$ \\
\hline \multirow{2}{*}{\multicolumn{8}{|c|}{$\begin{array}{l}\text { B. vulgaris } \\
\text { (cv Bordo 237) }\end{array}$}} \\
\hline & & & & & & & \\
\hline Note. $\mathrm{nr}-\mathrm{n}$ & & & & & & & \\
\hline
\end{tabular}

Similarly were analyzed 13 samples of cultivated beet B. vulgaris; in this case, the most ancient genotype was the sample of cultivar group Polosatochereshkovaya. The dendrogram (Fig., B) shows four clearly discriminated clusters. The first cluster includes cv. groups Dlinnochereshkovaya belaya, Turkestanskaya zelenolistaya, and Poludlinnaya krasnaya. This cluster is the most ancient, and it is adjacent to the outgroup formed by cv. group Polosatochereshkovaya. The other three clusters quite independently form the group of samples with less ancient origin than members of the previous cluster. In particular, the cluster including cv. groups Zimnyaya ovalnaya and Chardzhuyskaya is more ancient than the cluster of cv. groups Afyonkarahissarskaya and Adanskaya zheltaya. However, the latter are evolutionarily younger than cv. group Abkhazskaya zelenolistaya from the fourth cluster. This fourth cluster also includes cv. groups Kitayskaya belaya, Ramonskaya odnosemyannaya 47, Ekkendorfskaya zheltaya, and Bordo 237; the dendrogram shows these samples are "youngest" among the studied cultural beets. Polymorphisms of these beets revealed by comparative RAPD analysis are presented in Table 2.

2. Degree of RAPD-polymorphism of the 13 samples of Beta vulgaris from the World collection of N.I. Vavilov Research Institute of Plant Industry (VIR).

\begin{tabular}{|c|c|c|c|c|c|c|c|c|c|c|c|c|c|}
\hline $\begin{array}{l}\text { Sample } \\
\text { Sample }\end{array}$ & 1 & 2 & 3 & 4 & 5 & 6 & 7 & 8 & 9 & 10 & 11 & 12 & 13 \\
\hline & & & & & reque & c y of & o ly mo & phic b & $\mathrm{d} \mathrm{s}$ & & & & \\
\hline & 0.235 & 0.317 & 0.642 & 0.321 & 0.507 & 0.512 & 0.623 & 0.511 & 0.125 & 0.187 & 0.547 & 0.336 & 0.193 \\
\hline & 0.19 & 0.22 & 0.51 & 0.23 & $\begin{array}{l}\mathrm{S} 1 \\
0.40\end{array}$ & $\begin{array}{c}\mathrm{n} \text { n } \mathrm{n}- \\
0.40\end{array}$ & $\begin{array}{c}\text { e a ve r } \\
0.50 \\
\gamma^{2}\end{array}$ & $\begin{array}{r}\text { I n d e } x \\
0.40\end{array}$ & 0.13 & 0.16 & 0.42 & 0.24 & 0.17 \\
\hline 1 & & $<0.05$ & $<0.001$ & $\mathrm{nr}$ & $<0.01$ & $\mathrm{nr}$ & $\stackrel{\chi}{<}<0.01$ & $<0.001$ & $<0.01$ & $<0.05$ & $<0.01$ & $<0.05$ & $<0.01$ \\
\hline 2 & & & $<0.01$ & $<0.05$ & $<0.001$ & $<0.001$ & $<0.05$ & $\mathrm{nr}$ & $<0.05$ & $<0.01$ & $\mathrm{nr}$ & $<0.05$ & $<0.05$ \\
\hline 3 & & & & $<0.05$ & $<0.05$ & $<0.01$ & $<0.05$ & $<0.05$ & $<0.01$ & $\mathrm{nr}$ & $<0.01$ & $<0.05$ & $\mathrm{nr}$ \\
\hline 4 & & & & & $<0.01$ & $<0.05$ & $<0.05$ & $<0.01$ & $<0.001$ & $<0.01$ & $<0.05$ & $<0.05$ & $<0.01$ \\
\hline 5 & & & & & & $<0.001$ & $<0.01$ & $<0.01$ & $<0.05$ & $\mathrm{nr}$ & $<0.001$ & $\mathrm{nr}$ & $<0.001$ \\
\hline 6 & & & & & & & $<0.01$ & $<0.001$ & $<0.05$ & $<0.05$ & $<0.01$ & $<0.05$ & $<0.01$ \\
\hline 7 & & & & & & & & $<0.05$ & $<0.05$ & $<0.01$ & $<0.001$ & $<0.01$ & $<0.05$ \\
\hline 8 & & & & & & & & & $<0.01$ & $<0.05$ & $\mathrm{nr}$ & $<0.001$ & $<0.05$ \\
\hline 9 & & & & & & & & & & $<0.01$ & $<0.01$ & $<0.05$ & $\mathrm{nr}$ \\
\hline 10 & & & & & & & & & & & $<0.05$ & $<0.05$ & $<0.001$ \\
\hline 11 & & & & & & & & & & & & $\mathrm{nr}$ & $<0.01$ \\
\hline 12 & & & & & & & & & & & & & $<0.05$ \\
\hline
\end{tabular}

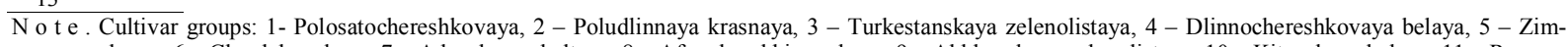
nyaya ovalnaya, 6 - Chardzhuyskaya, 7 - Adanskaya zheltaya, 8 - Afyonkarakhissarskaya, 9 - Abkhazskaya zelenolistaya, 10 - Kitayskaya belaya, 11 - Ramonskaya odnosemyannaya 47, 12 - Ekkendorfskaya zheltaya, 13 - Bordo 237 ; $\mathrm{nr}$ - not reliable.

So, wild and cultivated beets from the World collection of VIR were investigated by means of RAPD analysis, which revealed their molecular-genetic and phylogenetic relationships. In earlier works of other researchers, RAPD test was used for establishing genetic relationships within the genus Beta L. (33), constructing its genetic maps and saturating them with molecular markers (16), mapping QTLs for resistance to Beet Necrotic Yellow Vein Virus (BNYVV) $(34,35)$, as well as for identification and labeling of CMS genes (36). Genetic interactions of beets were determined using various molecular markers, such as intron sequences of chloroplasts (37), ribosomal nuclear DNA units (38), RFLP markers (39), repeated satellite and mitochondrial sequences (40, 41). These facts show a fairly wide range of molecular genetic tools and approaches involved in scientific researches primarily related to phylogenetic and taxonomic problems, as well importance of this problem.

Results of this work are in good agreement with the previously proposed classification of wild beets (10). In this 
classification, morphobiological characters of B. perennis, B. macrocarpa, B. maritima, and B. cicla were considered to postulate them as individual species, the most ancient of which are B. perennis and B. macrocarpa. At the same time, B. orientalis and B. spontaneus are close to each other and they can be considered as subspecies of $B$. maritima. Cultivars Dlinnochereshkovaya, Polosatochereshkovaya, Turkestanskaya, and Poludlinnaya were determined as primitive forms the most distant from modern cv. groups Bordo 237, Ekkendorfskaya zheltaya, and Ramonskaya odnosemyannaya 47, while cv. groups Abkhazskaya, Zimnyaya ovalnaya, and Adanskaya zheltaya - closest to modern cultural beets, and intermediate position belongs to cv. groups Chardzhuyskaya and Afyonkarahisarskaya (10), which is also consistent with findings of this research. Results of molecular genetic analysis have confirmed phylogenetic structure of the genus Beta L. proposed in 1983 by V.I. Burenina (42) that differs from the earlier classifications of other researchers (10).

So, in this work for the first time have been established phylogenetic relationships within and between the samples of wild, primitive, and cultural beets by means of classical morphobiological methods and molecular genetic analysis. The authors' findings are consistent with the old-established phylogenetic classification of species in the genus Beta L. (1983) and confirm its propriety. Data of RAPD-labeling can be used for characterization of samples preserved in the World collection of N.I. Vavilov Research Institute of Plant Industry (VIR), as well as in genetic and breeding studies and programs.

\section{REFERENCES}

1. Vavilov N.I. Teoreticheskie osnovy selektsii [Theoretical Fundamentals of Breeding]. Moscow, 1935.

2. Krasochkin V.T. Svekla. Kul'turnaya flora SSSR [Beet. Cultural Flora of the USSR]. Leningrad, 1971: 7-266.

3. Burenin V.I. Geneticheskie resursy roda Beta L. (svekla) [Genetic Resources of the Genus Beta L. (Beet)]. St. Petersburg, 2007.

4. Van Geyt J.P.C., Lange W., Oleo M., De Bock T.S.M. Natural variation within the genus Beta and its possible use for breeding sugar beet. Euphytica, 1990, 49: 5776.

5. Vavilov N.I. Zakon gomologicheskikh ryadov v nasledstvennoi izmenchivosti[The Law of Homological Series in Hereditary Variability]. Saratov, 1920.

6. Lewellen R.T. Pre-breeding sugar beet for virus and Rhizomania resistance (abstr.). A Report on the Third Int. Beta Genetic Resources Workshop and World Network Conference. Fargo, USA, 1993: 11.

7. Teurer J.C. Pre-breeding to change root architecture (abstr.). A Report on the Third Intrl. Beta Genetic Resources Workshop and World Network Conference. Fargo, USA, 1993: 11

8. Lange W., De Bock T.M.S., Lankhorst R.K. Pre-breeding for nematode resistance in beet (abstr.). A Report on the Third Intrl. Beta Genetic Resources Workshop and World Network Conference. Fargo, USA, 1993: 13.

9. Dalke L., Szota M. Possibility for utilizing the male sterility from Beta maritimain sugar beet breeding (abstr.). A Report on the Third Intrl. Beta Genetic Resources Workshop and World Network Conference. Fargo, USA, 1993: 14.

10. Burenin V.I., Pivovarov V.F. Svekla [Beet]. St. Petersburg, 1998.

11. Williams J.G.K., Kubilek A.R., Livak K.J., Rafalski J.A., Tingey S. DNA polymorphism ampliphied by arbitrary primers are useful as genetic markers.Nucl. Acid Res., 1990, 18: 6531-6535.

12. Chesnokov Yu.V. Geneticheskie resursy rastenii i sovremennye metody DNK-tipi-rovaniya [Genetic Resources of Plants and Modern Methods of DNA-

Fingerprinting]. St. Petersburg, 2007.

13. Chesnokov Yu.V. Sel'skokhozyaistvennaya Biologiya [Agricultural Biology],2005, 1: 20-40.

14. Potokina E.K., Chesnokov Yu.V. Sel'skokhozyaistvennaya Biologiya[Agricultural Biology], 2005, 3: 3-18.

15. Barzen E., Mechelke W., Ritter E., Shulte-Kappert E. An extended map of the sugar beet genome containing RFLP and RAPD loci. Theor. Appl. Genet., 1995, 90: 189-193.

16. Nilsson N.-O., Hallden C., Hansen M., Hjerdin A., Säll T. Comparing the distribution of RAPD and RFLP markers in high density linkage map of sugar beet.Genome, 1997, 40: 644-651.

17. Abe J., Yoshikawa H., Tsuda C. Genetic analysis for annularity and self fertility in wild relatives of sugar beet, made by using the pigment gene and some enzyme loci as markers. Proceeding of the Sugar Beet Reseach Association (Japan), 1985, No. 27.

18. Abe J., Tsuda C. Genetic analysis for enzyme variation in the sectionVulgares, genus Beta. Japan. J. Breed., 1987, 37: $253-261$.

19. Sabir A., Newbury H.J., Todd G., Catty J.P., Ford-Lloyd B.V. Determination of genetic stability using isozymes and RFLPs in beets plants regenerated in vitro. Theor. Appl. Genet., 1992, 84: 113-117.

20. Mita G., Dani M., Casciari P., Pasquqli A., Selva E., Minganti C., Piccardi P. Assessment of the degree of genetic variation in beet based on RFLP analysis and taxonomy of Beta. Euphytica, 1991, 55: 1-6.

21. Nagamine T., Catty J.P., Ford-Lloyd B.V. Phenotypic polymorphism and allele differentiation of enzymes in fodder beet, multigerm sugar beet monogerm sugar beet. Theor. Appl. Genet., 1987, 77: 711-720.

22. Levall M.W., Bengtsson K., Nilsson N., Hjerdin A., Hallden C. Molecular characterization of UV-treated beet somaclones using RFLP markers. Physiologia Plantarum, 1994, 90: 216-220.

23. Boundry P., Weiber R., Saumitou-Laprade P., Pillen K., Van Dijk H., Jung C. Identification of RFLP markers closely linked to the bolting gene $B$ and their significance for the study of the annual habit in beets (Beta vulgaris L.). Theor. Appl. Genet., 1994, 88: 852-858.

24. Salontijin E.M.J., Sandal N.N., Klein-Lankhorst R., Lange W., De Bock T.H., Marcker K.A., Stiekema W.J. Long-range organization of the satellite DNA family flanking the beet cyst nematode resistance locus $(H s I)$ on chromosome 1 of B. patellaris and procumbens. Theor. Appl. Genet., 1994, 89: 459-466.

25. Lorenz M., Weihe A., Borner T. DNA fragments of organellar origin in random ampliphied polymorphic DNA (RAPD) patterns of sugar beet (Beta vulgaris L.).Theor. Appl. Genet., 1994, 88: 775-779.

26. Senda M., Onodera Y., Kinoshita T., Mikami T. Mitochondrial gene variation and the relationships in the genus Beta. Theor. Appl. Genet., 1995, 90: 914-919.

27. Dorokhov D.B., Kloke E. Bystraya i ekonomichnaya tekhnologiya RAPD analiza rastitel'nykh genomov. Genetika, 1997, $33(4): 358-365$.

28. Virk P.S., Ford-Lloyd B.V., Jackson M.T., Newbury H.J. Use of RAPD for the study of diversity within plant germplasm collections. Heredity, 1995, 74: $170-179$.

29. Nei M., Li W.H. Mathematical model for studying genetic variation in terms of restriction endonuclease. PNAS USA, 1979 , 76: $5269-5273$.

30. Hennink S., Zeven A.C. The interpretation of Nei and Shannon-Weaver index within population variation indexes. Euphytica, 1990, 51: 235-240.

31. Sneath P.H.A., Sokal R.R. Numerical taxonomy. Freeman, San Francisco, 1973.

32. Rohlf F.J. NTSYS-pc numerical taxonomy and multivariate analysis system. Exeter, NY, 1992.

33. Shen Y., Ford-Lloyd B.V., Newbury H.J. Genetic relationships within the genus Beta determined using both PCR-based marker and DNA sequencing techniques. Heredity, 1998, 80: 624-632.

34. Grimmer M.K., Trybush S., Hanley S., Francis S.A., Karp A., Asher M.J.C. An anchored linkage map for sugar beet based on AFLP, SNP and RAPD markers and QTL mapping of a new source of resistance to Beet necrotic yellow vein virus.Theor. Appl. Genet., 2007, 114: 1151-1160.

35. Scholten O.E., Klein-Lankhorst R.M., Esselink D.G., De Bock T.S.M.,

Lange W. Identification and mapping of random polymorphic DNA (RAPD) markers linked to resistance against beet necrotic yellow vein virus (BNYVV) in Betaaccessions. Theor. Appl. Genet., 1997, 94: 123-130.

36. Hagihara E., Itchoda N., Habu Y., Iida S., Mikami T., Kubo T. Molecular mapping of a fertility restorer gene for Owen cytoplasmic male sterility in sugar beet. Theor. Appl. Genet., 2005, 111:250-255.

37. Mglinets A.V. Doklady Akademii nauk, 2008, 420: 556-558.

38. Saltoni S., Berville A. Characterization of the nuclear ribosomal DNA units and phylogeny Beta L. wild forms and cultivated beets. Theor. Appl. Genet., 1992, 83: $533-542$.

39. Jung C., Pillen K., Frese L., Fähr S., Melchinger A.E. Phylogenetic relationships between cultivated and wild species of the genus Beta revealed by DNA «fingerprinting». Theor. Appl. Genet., 1993, 86: 449-457.

40. Kubis S., Heslop-Harrison J.S., Schmidt T. A family of differentially amplified repetitive DNA sequences in the genus Beta reveals genetic variation in Beta vul- 
garis subspecies and cultivars. J. Mol. Evol., 1997, 44: 310-320.

41. Nishizawa S., Mikami T., Kubo T. Mitochondrial DNAphylogeny of cultivated and wild beets: relationships among cytoplasmic male-sterility-inducing and nonsterilizing cytoplasms. Genetics, 2007, 177: 1703-1712.

42. Burenin V.I. Svekla - Beta L. (sistematika, genetika, iskhodnyi material i metody selektsii). Doktorskaya dissertatsiya [Beet - Beta L. (Systematics, Genetics, Source Material and Breeding Metho)]. Leningrad, 1983. 